\title{
Endoscopic Treatment of Anastomotic Bleeding in Laparoscopic Colorectal Surgery
}

\author{
Giulio Mari, Andrea Costanzi, Jacopo Crippa, Valter Berardi, Letizia Santurro, Valentina Riggio, Martino Gerosa, \\ Gianluigi Corti. Dario Maggioni
}

General Surgery Department, Desio Hospital, Lombardy, Italy

Corresponding author:

Giulio Mari MD.

General Surgery Department

Desio Hospital Lombardy, Italy

$\mathrm{Tel}+393281245874$

E-mail: giul_mari@yahoo.it
Received: 22.01 .2019 Accepted: 25.03 .2019

\section{Rezumat \\ Tratamentul endoscopic al sângerărilor anastomotice în contextul cirurgiei laparoscopice colorectale}

Sângerarea de la nivelul liniei de anastomoză mecanică reprezintă o complicație relativ rară însă potențial fatală, care impune tratament de urgență. Abordul terapeutic al hemoragiilor anastomotice mecanice poate fi atât operativ cât şi conservator. În continuare vom prezenta o serie de 3 cazuri de sângerare de la nivelul liniei de anastomoză mecanică în contextul unei operații colorectale, care au fost rezolvate prin abord endoscopic. Operația practicată în prealabil la cei 3 pacienți a constat în rezecție rectală anterioară înaltă, cu anastomoză transanală Knight-Griffen, efectuată cu stapler circular. Indicația operatorie a a fost reprezentată de: adenocarcinom rectal, endometrioză rectală şi, respectiv, boală diverticulară. Toți cei 3 pacienți au prezentat sângerare rectală importantă în primele 24 de ore postoperator. Unul dintre pacienți a beneficiat de endoscopie hemostatică în cursul intervenției chirurgicale per se. S-a efectuat lavaj endoscopic, cu îndepărtarea subsecventă a cheagurilor. În cursul aceleiaşi intervenții s-au efectuat infiltrații cu Adrenalină 1:10000 $(2 \mathrm{ml})$ ale punctelor de sângerare situate de-a lungul liniei de anastomoză mecanică, ceea ce a realizat o hemostază satisfăcătoare. Endoscopia hemostatică practicată precoce în cursul hemoragiilor postoperatorii reprezintă o abordare terapeutică sigură şi eficientă a sângerarilor anastomotice din sfera colorectală.

Cuvinte cheie: tratament endoscopic, sângerare anastomotică, chirurgie colorectală, linie de anastomoză mecanică, eliminarea cheagurilor, injectare de adrenalină, laparoscopie 


\section{Abstract}

Bleeding from the stapled line is a rare but potentially lethal complication that requires a proper and immediate management. Treatment for stapled anastomotic hemorrhage may be operative or conservative. We report three cases of anastomotic stapled line bleeding after colorectal surgery successfully treated endos-copically. Laparoscopic High Anterior Resection with a trans anal anastomosis according to Knight-Griffen with circular a stapler was performed for adenocarcinoma, rectal endometriosis and diverticular disease. All three patients had major rectal bleeding within 24 hours from surgery. 1 patients had endoscopy before the end of the surgical procedure. Endoscopic wash out with removal of the clots and infiltration of the bleeding sites along the stapled line with Adrenaline 1: $10000(2 \mathrm{ml})$ was performed achieving a good hemostasis. Early endoscopy is a safe and efficient treatment in colorectal anastomotic bleeding.

Key words: endoscopic treatment, anastomotic bleeding, colo-rectal surgery, staple line, clot wash out, adrenaline injection, laparoscopy

\section{Introduction}

The safety of colorectal surgery has radically improved over the last years due to improvements in preoperative preparation, antibiotic prophylaxis, surgical technique and devices (1). Nevertheless, complications such as anastomotic leak and anastomotic bleeding still occur. Fortunately as well as the surgical technique also the possibilities and the modality 'to successfully treat even the most serious post-operative complications are definitely improved $(2,3)$.

Circular stapler devices for anastomosis after laparoscopic colon resection (LCR) is considered to be safe and widely accepted for restoring continuity of the lower gastrointestinal tract (4). Most laparoscopic colorectal anastomoses are in fact performed using staplers (5). In particular left sided colonic cancer and rectal cancer are nowadays routinely approached with the use of staplers (4). The introduction of laparoscopy made the use of circular staplers mandatory in order to perform a fully laparoscopic procedure. Technical aspects of these devices have been improved through years and surgeons's skills and experience have grown exponentially since laparoscopy became widespread (6).

The main complication after colorectal surgery is anastomotic leak. Beside this, bleeding from the stapled line is a rare but potentially lethal complication that requires a proper and immediate management (7). The incidence of anastomotic bleeding is reported in the literature as $0.5 \%$ to $9.6 \%(8,9)$.

Generally, its presentation consists of limited haematochezia associated to the first bowel movement. Usually, although it can be a common event, rectal bleeding following colorectal anastomosis is self-limited (7), but severe bleeding can occur in about $1 \%$ of patients (10).

Treatment for stapled anastomotic hemorrhage may be operative or conservative. When conservative such a behavior involves observation, blood transfusion, rectal packing. More invasive and operative solutions may be endoscopy, angiography, and finally a surgical approach.

A different assessment is made when bleeding occursin the operating theater. Intraoperative endoscopy in such cases allows to direct visualization of the anastomotic bleeding and, if possible, hemostasis (9).

\section{Case Series}

Between September 2014 and March 2016 three patients ( 2 women and 1 man) underwent elective Laparoscopic High Anterior Resection (HAR). Patient 1 was a 73 years old male with a diagnosis of diverticular disease of the descending colon and of the sigmoid colon 
complicated with a stenosis of the sigma documented by colonoscopy and contrast enhanced enema. Patients referred several episodes of abdominal pain associated with difficulties in passing stool in the late three years. Beside this past clinic history was quite silent. Patient was not assuming any anti-coagulating drug and ASA score was 2 for Hypertension.

Patient 2 was a 79 years old woman affected by Adenocarcinoma of the sigma diagnosed by pre-operative colonoscopy. CT scan of abdomen and thorax was performed to stage the disease not showing any metastasis. Patient was classified ASA 2 for the age. She was not assuming therapies before surgery.

Patient 3 was a 33 years old female affected by pelvic endometriosis with a CT scan evidence of an endometriosis node involving the left ovarian and the upper rectum. Patient referred difficulties in passing stool and chronic pelvic pain. Colonoscopy described a sub-stenosis of the sigmoid-rectum joint. Patient was classified ASA 1 and was not assuming any therapy.

HAR was performed $(11,12)$ with mobilization of the splenic flexure, ligation of the inferior mesenteric artery at the origin, trans anal anastomosis according to Knight-Griffen with circular a stapler.

In all cases pneumatic test was performed showing no anastomotic air leak. All patients had digital check of the rectum after anastomosis was performed.

Patient 1 started profuse rectal bleeding after return to surgical ward. Patient 2 had bleeding in the operating room (OR) noticed after digital check of the anastomosis. Patient 3 had hypovolemic shock $8 \mathrm{~h}$ from surgery that required admission in Intensive Care Unit (ICU) where rectal bleeding occurred.

\section{Surgical Data}

Mean time of surgery for the three patients was $185 \mathrm{~min}$. None of them received intraoperative blood transfusions nor had hypotension through the procedure. Proximal colonic stump was check for good remnant blood supply before performing anastomosis. Anastomoses underwent pneumatic and digital exploration control. All patients had an intra-operative $\mathrm{Hb}$ examination that did not show significant decrease in $\mathrm{Hb}$ levels.

\section{Bleeding management}

Patient 1 started with rectal bleeding once back in surgical ward from OR. Hb level decreased to $9,5 \mathrm{mg} / \mathrm{dl}$ from $14,2 \mathrm{mg} / \mathrm{dl}$, Hct $28,1 \%$ from initial $35,1 \%$. Transfusion of 3 baxters of GRC and 3 baxters of PLASMA stabilized $\mathrm{Hb}$ levels but the profuse rectal bleeding led patient to OR were endoscopy was performed finding clots above the anastomosis and fresh blood in the rectal ampulla. Management consisted in anastomosis wash out with removal of the clots and infiltration of the bleeding sites along the stapled line with Adrenaline $1: 10000(2 \mathrm{ml})$ achieving a good hemostasis.

Patient 2 received colonoscopy before the end of the procedure after free blood in the rectal ampulla was detected during digital check of the performed anastomosis. Colonoscopy found $300 \mathrm{ml}$ of fresh blood in the rectal ampulla. After blood clots wash out and injection of Adrenaline 1: $10000(4 \mathrm{ml})$ along the stapled line bleeding control was achieved. Patient 3 presented hypovolemic shock $8 \mathrm{~h}$ from surgery. Patient was transferred in ICU. $\mathrm{Hb}$ level crashed down to $7 \mathrm{mg} / \mathrm{dl}$ from initial $11,2 \mathrm{mg} / \mathrm{dl} .3$ Baxter of fresh blood and 3 of plasma transfusion with vasoactive amine could managed to raise blood pressure to 100/60. Finding of rectal bleeding happened subsequently hypovolemic shock. Colonoscopy was then performed in OR showing blood clot on the posterior aspect of the anastomosis. After removal of the clot and wash out of the ampulla remnant bleeding was stabilized with injection of Adrenaline 1: 10000 (3 ml). All patient did not have recurrent bleeding after endoscopic treatment. Haemodynamic parameters normalized without need of other transfusions. All patient were discharged with an $\mathrm{Hb}$ value in normality range. 


\section{Discussion}

Limited haematochezia with the first bowel movement is a common finding in patients with colo-rectal anastomosis. Major rectal bleeding is fortunately a very rare complication. It's incidence has been reported to be approximately $1 \%$ of cases after stapled colorectal anastomoses $(7,13)$. Anticoagulant or antiaggregant therapy are reported to increase the risk of lower gastrointestinal bleeding after colorectal surgery. The three reported cases nevertheless were not assuming any bleeding increasing risk therapy.

Recently the Cochrane Group analysis suggested that the risk of anastomotic bleeding was higher with the stapled procedure in comparison to the hand-sewn technique. However during laparoscopic left sided procedures, for practical reasons, colorectal anastomoses are performed mechanically $(14,15)$.

Presentation of symptoms can be insidious and hypotensive shock can onset before rectal bleeding becomes evident. Routinely use of intraoperative colonoscopy for the evaluation of circular-stapled anastomosis could significantly reduce the incidence complications following anastomotic post-operative bleeding although being debated (5). Patient number 2 in fact had straight and normal post-operative period due to the early detection of stapled line bleeding. Discharge happened on day 6. Our reported small series of course does not provide sufficient evidence supporting routine verus selective use of intraoperative colonoscopy thus confirming other studies (13). Intra-operative endoscopy can in fact prolong operating time significantly. Therefore digital check of the stapled line is normally preferred and should be always performed even if it can not be the only examination to relay on. The control of hemodynamic parameters in the immediate post-operative and the timeliness in the endoscopic approach to the anastomotic bleeding are the cornerstones of an effective and successful treatment. When rectal bleeding occurs it is necessary to rapidly estimate blood loss in order to assess which kind of management bleeding requires. Some authors suggest the routinely use of trans-anal drainage tube in anterior resection for rectal cancer as a simple, safe, and effective means to prevent or reduce the occurrence of anastomotic leakage and bleeding (16).

Haemodinamic parameters have to be taken into consideration even when rectal bleeding seems to be limited. Avoiding delay in performing operative hemostatic procedures is a key factor in the outcome of these patients. Hypovascolarization of the anastomosis due to stapled line bleeding can lead to tissue suffering and therefore to anastomotic leak (17). The early endoscopic approach can guarantee a good view of the bleeding site, giving an appropriate estimation of blood loss (18). Hemostasis can be achieved by injection of vasoconstrictor drugs associated to blood clots wash out $(19,20)$. Hemostasis check can be done by watchful endoscopic waiting. All three patients we report had successful bleeding control without remnant haemotochezia. No post-endoscopy transfusion was required. $\mathrm{Hb}$ levels at discharge were within range of normality. Staple line irrigation with saline to remove clots seems to enhance stopping in bleeding (21).

Performing colonoscopy in an operating room with an endoscopy dedicated surgeon or gastroenterologist is recommended. Patients with a major colonic bleeding may in fact need intubation and conversion to major abdominal procedure all of a sudden. Endoscopic treatment of major post-operative bleeding should therefore be approached by a skilled and experienced endoscopist to achieve a successful adrenaline hemostasis and to avoid second look surgery preserving patients $(10,22-24)$.

\section{Conclusion}

Stapled line bleeding after colorectal anastomosis can in rare cases be a lethal complication. It normally happens within the first 24 $\mathrm{h}$ after surgery. Evidence of rectal bleeding can happen after hypotension occurs. Real entity of blood loss has to be rapidly assessed. Early endoscopic treatment with wash out of clots and adrenaline injection of the staples line is a safe, effective and 
successful approach. Routinary use of intraoperative colonoscopy should be taken into consideration in early detection and treatment of post-operative bleeding. However provided data are limited and further metaanalysis studies are needed.

\section{Conflict of Interest}

The authors declare no conflicts of interests.

\section{Refereces}

1. Paun BC1, Cassie S, MacLean AR, Dixon E, Buie WD. Postoperative complications following surgery for rectal cancer. Ann Surg. 2010; 251(5):807-18.

2. Besson R, Christidis C, Denet C, Bruyns L, Levard H, Gayet B. Management of postoperative bleeding after laparoscopic left colectomy. Int J Colorectal Dis. 2016;31(8):1431-1436.

3. Perez RO, Sousa A Jr, Bresciani C, Proscurshim I, Coser R, Kiss D, et al. Endoscopic management of postoperative stapled colorectal anastomosis hemorrhage. Tech Coloproctol 2007;11(1):64-66.

4. Shamiyeh A, Szabo K, Ulf Wayand W, Zehetner J. Intraoperative endoscopy for the assessment of circular-stapled anastomosis in laparoscopic colon surgery. Surg Laparosc Endosc Percutan Tech. 2012;22(1):65-7.

5. Li VK, Wexner SD, Pulido N, Wang H, Jin HY, Weiss EG, et al. Use of routine intraoperative endoscopy in elective laparoscopic colorectal surgery: can it further avoid anastomotic failure? Surg Endosc. 2009;23(11):2459-65.

6. Memon AA, Marks CG. Stapled anastomoses in colorectal surgery: a prospective study. Eur J Surg. 1996;162(10):805-10.

7. Martínez-Serrano MA, Parés D, Pera M, Pascual M, Courtier R, Egea MJ, et al. Management of lower gastrointestinal bleeding after colorectal resection and stapled anastomosis. Tech Coloproctol. 2009;13(1):49-53.

8. Ishihara S, Watanabe T, Nagawa H. Intraoperative colonoscopy for stapled anastomosis in colorectal surgery. Surg Today. 2008; 38(11):1063-5.

9. Li VK, Wexner SD, Pulido N, Wang H, Jin HY, Weiss EG, et al. Use of routine intraoperative endoscopy in elective laparoscopic colorectal surgery: can it further avoid anastomotic failure? Surg
Endosc. 2009;23(11):2459-65.

10. Cirocco WC, Golub RW. Endoscopic treatment of postoperative hemorrhage from a stapled colorectal anastomosis. Am Surg. 1995;61(5):460-3.

11. Koh CE, Juszczyk K, Cooper MJ. Management of deeply infiltrating endometriosis involving the rectum. Dis Colon Rectum. 2012; 55(9):925-31.

12. Jelenc F, Ribič-Pucelj M, Juvan R. Laparoscopic rectal resection of deep infiltrating endometriosis. Laparoendosc Adv Surg Tech A. 2012;22(1):66-9.

13. Clifford RE, Fowler H, Govindarajah N, Vimalachandran D, Sutton PA. Surg Endosc. Early anastomotic complications incolorectal surgery: asystematic review of techniques for endoscopic salvage. Surg Endosc. 2019;33(4):1049-1065.

14. Ho YH, Ashour MA. Techniques for colorectal anastomosis. World J Gastroenterol. 2010;16(13):1610-21

15. Neutzling CB, Lustosa SA, Proenca IM, da Silva EM, Matos D. Stapled versus handsewn methods for colorectal anastomosis surgery. Cochrane Database Syst Rev. 2012;2:CD003144.

16. Zhao WT, Hu FL, Li YY, Li HJ, Luo WM, Sun F. Use of a transanal drainage tube for prevention of anastomotic leakage and bleeding after anterior resection for rectal cancer. World J Surg. 2013;37(1): 227-32.

17. Davis B, Rivadeneira DE. Complications of colorectal anastomoses: leaks, strictures, and bleeding. Surg Clin North Am. 2013;93(1): 61-87.

18. Malik AH, East JE, Buchanan GN, Kennedy RH. Endoscopic haemostasis of staple-line haemorrhage following colorectal resection. Colorectal Dis. 2008;10(6):616-8.

19. Frossard JL, Gervaz P, Huber O. Water-immersion sigmoidoscopy to treat acute Gl bleeding in the perioperative period after surgical colorectal anastomosis. Gastrointest Endosc. 2010;71(1):167-70.

20. Ozaslan E, Purnak T, Tenlik I, Yildiz A, Haznedaroglu IC. An alternative hemostatic method for early Gl bleeding caused by anastomotic ulcer. Gastrointest Endosc. 2010;72(4):902-3.

21. Laine L, Stein C, Sharma V. A prospective outcome study of patients with clot in an ulcer and the effect of irrigation. Gastrointest Endosc. 1996;43(2 Pt 1):107-10.

22. Khoury W, Lavery IC, Kiran RP. Impact of early reoperation after resection for colorectal cancer on long-term oncological outcomes. Colorectal Dis. 2012;14(3):e117-23.

23. Fazio VW, Tekkis PP, Remzi F, Lavery IC. Assessment of operative risk in colorectal cancer surgery: the Cleveland Clinic Foundation colorectal cancer model. Dis Colon Rectum. 2004;47(12):2015-24.

24. Lou Z, Zhang W, Yu E, Meng R, Fu C. Colonoscopy is the first choice for early postoperative rectal anastomotic bleeding. World $\mathrm{J}$ Surg Oncol. 2014;12:376 